Daniel Edison M. Husana. Sundathelphusa prosperidad, sp. n. (decapoda: brachyura: gecarcinucidae), a new cave-obligate freshwater crab from Mindanao Island, the Philippines, with notes on the conservation status of Philippine cave species.. Journal of Cave and Karst Studies, v. 82 , no. 3, p. 210-218. DOI:10.4311/2019LSC0116

\title{
SUNDATHELPHUSA PROSPERIDAD, SP. N. (DECAPODA: BRACHYURA: GECARCINUCIDAE), A NEW CAVE-OBLIGATE FRESHWATER CRAB FROM MINDANAO ISLAND, THE PHILIPPINES, WITH NOTES ON THE CONSERVATION STATUS OF PHILIPPINE CAVE SPECIES
}

\author{
Daniel Edison M. Husana
}

\begin{abstract}
A new species of cave-obligate freshwater crab of the genus Sundathelphusa Bott, 1969 (Gecarcinucidae) from Agusan del Sur, Philippines is described. The new species is morphologically close to S. hades Takeda and Ng, 2001 but distinctly differs in the shape of carapace and gonopods. Although the new species is found close to the type locality of $S$. hades, the morphological features are distinct and their habitats are separated by an extension of the Philippine faultline and Oligocene-Miocene volcanic deposits. Six Sundathelphusa species having true troglobiomorphic characters are now recorded from caves in the Philippine archipelago.
\end{abstract}

\section{Introduction}

A significant number of cavernicolous crab species have been recorded from the Philippines. Eight species of freshwater crabs with various degrees of cave adaptations, all belonging to the genus Sundathelphusa Bott, 1969 of the family Gecarcinucidae Rathbun, 1904, have been described from different caves in the Philippine archipelago. Two of these species were described from Bantakay Cave in the northern island of Luzon, i.e. S. holthuisi $\mathrm{Ng}, 2010$ and S. danae Husana, Yamamuro and Ng, 2014, while S. niwangtiil Husana, Kase and Mendoza, 2015, was described from Mabinay Cave in Negros Island. These three species exhibit partial cave adaptations, i.e. elongated slender ambulatory legs in proportion to their body size. Five species exhibit more advanced troglomorphism, with reduced eyes, elongated legs and loss of pigment. These are S. cavernicola Takeda, 1983 and S. sottoae $\mathrm{Ng}$ and Sket, 1996 from Bohol Island; S. hades Takeda and Ng, 2001 from Mindanao Island; S. waray Husana, Naruse and Kase, 2009 and S. lobo Husana, Naruse and Kase, 2009, from Samar Island.

The new species, Sundathelphusa prosperidad, described here is the ninth species in the genus and also exhibits advanced troglomorphism. It is the second cave-obligate crab recorded from the island of Mindanao.

Although other species of Sundathelphusa such as S. philippina (von Martens, 1868), S. boex Ng and Sket, 1996, S. vedeniki $\mathrm{Ng}$ and Sket, 1996, S. urichi $\mathrm{Ng}$ and Sket, 1996, S. vienae Husana, Yamamuro and Ng, 2014, and S. quirino Husana and $\mathrm{Ng}, 2019$ were recorded from caves in various islands of the Philippines, these species do not exhibit any troglomorphic features. However, S. vedeniki and S. urichi have slightly reduced eyes and shortened eyestalks with noticeable reduction in the body pigmentation in the latter species ( $\mathrm{Ng}$ and Sket, 1996). Sundathelphusa spelaeophila Stasolla, Abbarchi and Innocenti, 2015, was described from a cave but has no cave-adapted characters and is a junior synonym of $\mathrm{S}$. philippina sensu stricto (Husana and $\mathrm{Ng}, 2019$ ). All these species are just surface organisms that regularly enter and stay inside, near the entrance of the cave, for shelter during the day. It is important to note that Sundathelphusa species in the Philippines evolved rapidly as Klaus et al. (2013) demonstrated on the character change following the transition from surface to subterranean life of the five species of this freshwater crab in Bohol Island based on molecular genetic analyses.

Other species of cave crabs from the Philippines have been described and recorded from anchialine caves in various islands of the archipelago. These include species of Varunidae family, i.e. Orcovita tabiacoud Stasolla and Innocenti, 2014, from Pukaway Cave, Coron Island; O. holthuisi $\mathrm{Ng}$ and $\mathrm{Ng}, 2009$, from Pukaway Cave, Coron Island; O. angulata Ng, Guinot and Iliffe, 1996 from Pukaway Cave, Coron Island; O. fictilia Ng, Guinot and lliffe, 1996, Hinagdanan Cave, Panglao Island; Hymenosomatidae family, i.e. Samarplax principe Husana, Tan and Kase, 2011, Principe Cave, Guiuan Island; Sesarmidae family, i.e. Karstarma philippinarum Husana, Naruse and Kase, 2010, Bat Cave, Boracay Island and Tagbaobo Cave, Samal Island; K. boholano Ng, 2002, Tawala Cave, Panglao Island; K. sulu Ng, 2002, St. Paul N. P. Cave, Palawan Island; Gecarcinidae, i.e. Discoplax gracilipes Ng and Guinot, 2001, Virata Cave, Panglao Island, but my extensive field research shows that this latter species is widespread in many caves in karstic islands in the Philippines. Of these species, only S. principe has the complete troglomorphic features, while others have just elongated legs and/or slight eye reduction as the only cave adaptations.

Institute of Biological Sciences, College of Arts and Sciences, University of the Philippines Los Baños College, Laguna 4031, Philippines E-mail: dmhusana@up.edu.ph 


\section{Materials and Methods}

Materials were collected using opportunistic sampling methods from a cave on Mindanao Island. A minimal number of samples were hand-picked to avoid high impact that might cause population decline. They were treated with $10 \%$ formalin for a week after anesthetizing them in the freezer for about an hour. Specimens were transferred to $70 \%$ ethanol after rinsing in fresh flowing water for a few hours. Photographs of live individuals were taken in the field. Photographs of important parts for the description of the specimen were taken from the preserved holotype at the lab using a Canon 70D camera. Figures were made using a Nikon camera lucida.

Measurements provided are the maximum carapace width (CW) by carapace length (CL). The terminology follows that by $\mathrm{Ng}$ and Sket (1996) with modifications as recommended by Davie et al. (2015). Specimens were deposited at the National Museum of the Philippines, Manila (NMCR) and Zoological Reference Collection (ZRC) Lee Kong Chian Natural History Museum, National University of Singapore. The abbreviations G1 and G2 are used for male first and second gonopods, respectively.

\section{Systematics}

Family Gecarcinucidae Rathbun, 1904

Genus Sundathelphusa Bott, 1969

Sundathelphusa prosperidad, new species

Figs. 1-4

Material examined. - Holotype: Male $(30.68 \times 22.3 \mathrm{~mm})$, NMCR 50776, Ognop Cave, Prosperidad, Agusan del Sur, Philippines, 345mASL. D.E. Husana and A. Pasilan, 14 May 2014. Paratypes: female $(28.04 \times 21.38 \mathrm{~mm})$, NMCR 50777, same data as holotype; male $(20.58 \times 16.67 \mathrm{~mm})$, female $(25.77 \times 20.19 \mathrm{~mm})$, NMCR 50778, Lorenzo Cave, Prosperidad, Agusan del Sur, Philippines. A. Pasilan, January 2014; Male $(25.74 \times 19.33 \mathrm{~mm})$, Females $(26.16 \times 19.91$ mm; $22.69 \times 18.02$ mm) NMCR 57081, Ognop Cave, Prosperidad, Agusan del Sur, Philippines, 345mASL. D.E. Husana and A. Pasilan, 14 May 2014; male $(25.33 \times 20.2 \mathrm{~mm})$, female $(28.33 \times 22.62 \mathrm{~mm})$, NMCR 50779, Ognop cave, Prosperidad, Agusan del Sur, Philippines, 345mASL. D.E. Husana and A. Pasilan, 1 May 2012; male $(25.29 \times 19.79$ $\mathrm{mm}$ ), ZRC 2019.0876, Ognop cave, Prosperidad, Agusan del Sur, Philippines, 345mASL. D.E. Husana and A. Pasilan, 1 May 2012; female $(24.68 \times 19.61 \mathrm{~mm})$, ZRC 2019.0877 , males $(25.92 \times 21.1 \mathrm{~mm} ; 24.4 \times 20.62 \mathrm{~mm} ; 26.54 \times 20.89$ mm), NMCR 50780, Ognop cave, Prosperidad, Agusan del Sur, Philippines, 345mASL. A. Pasilan, 20 Nov. 2011.

Comparative materials. - Sundathelphusa cavernicola Takeda 1983: holotype female $(25.7 \times 21.0 \mathrm{~mm})$, NSMT-Cr 8937, Quinapon-an Cave, Antequera, Bohol, Philippines, 949'38”N, 12354'10”E, coll. S. I. Ueno, 4 March 1983 ; 1 male $(18 \times 15.4 \mathrm{~mm}), 1$ female $(29.2 \times 24 \mathrm{~mm})$, NSMT-Cr 14130, Bongkawi Cave, Antequera, Villa Aurora, Bohol, Philippines, coll. P. K. L. Ng, 16 December 2000; 1 male $(26.5 \times 21.6 \mathrm{~mm}), 2$ females $(23.1 \times 18.1,26.5 \times 21.8 \mathrm{~mm})$, ZRC 2000.2079, Bongkawi Cave, Antequera, Villa Aurora, Bohol, Philippines, coll. B. Sket, 23 February 1999; 1 female $(22.2 \times 17.8 \mathrm{~mm})$, ZRC 2001.0335, Bongkawi Cave, Antequera, Villa Aurora, Bohol, Philippines, coll. P. K. L. Ng, December 2000; 3 males (13.0 × 15.1-0.8 × $24.1 \mathrm{~mm})$, Canantong Uno cave, Quinapon-an, Antequera, Villa Aurora, Bohol, Philippines, coll. B. Sket, 25 February 1999. Sundathelphusa sottoae Ng and Sket, 1996: 1 female $(26.2 \times 21.1$ mm), ZRC 1996.1553, paratype, Bonugan, Batuan, Bohol, Philippines, coll. B. Sket, February 1995; $1=(17.5 \times 14.4$ $\mathrm{mm})$, ZRC 1996.1548, open well, Batuan, Bohol, Philippines, coll. B. Sket, February 1995; 1 male $(18.0 \times 14.9 \mathrm{~mm})$, ZRC 2001.0343, Bongkawi Cave, Antequerra, Villa Aurora, Bohol, Philippines, coll. P. K. L. Ng, 16 December 2000. Sundathelphusa hades Takeda and Ng, 2001: holotype male $(19.7 \times 16.4 \mathrm{~mm})$ NSMT-Cr 14274, Latay Cave, Agusan

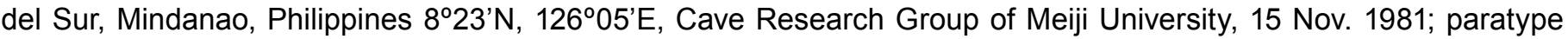
female $(24.9 \times 20.8 \mathrm{~mm})$ ZRC- 2001.1000, Sta. Rita Thinking Cave, Surigao del Sur, Mindanao, Cave Research Group of Meiji University, 27 Nov. 1998. Sundathelphusa waray Husana, Naruse and Kase 2009: holotype male (33.4 $\times 25.8$ $\mathrm{mm}$ ), NMCR 27059, Langun Cave, Calbiga, Western Samar, Philippines, $11^{\circ} 39.022^{\prime} \mathrm{N}, 15^{\circ} 02.991^{\prime} \mathrm{E}$, coll. D. E. Husana, 28 October 2006. Sundathelphusa lobo Husana, Naruse and Kase 2009: holotype male ( $31.5 \times 24.3 \mathrm{~mm})$, NMCR 27061, Lobo Cave, Jiabong, Western Samar, Philippines 1146.786’'N, 12455.732'E, coll. D. E. Husana, 1 August 2006.

Description. - Carapace quadrate to trapezoidal in shape, widest breadth at anterior quarter, dorsal surface convex longitudinally (Figs. 1A, 1M). Frontal region sloping antero-ventrally; branchial regions moderately inflated, with oblique rows of granules of various shapes and lengths; cervical grooves deep; $\mathrm{H}$-shaped median groove deep; epigastric and postorbital with cristae, not confluent; epigastric cristae separated from each other by deep cleft. Frontal margin broadly protruded, two lobes clearly separated with deep broad median concavity; external orbital tooth low, outer margin slightly longer than inner margin, margins granulated; epibranchial tooth small, low, separated from external orbital tooth by deep notch, inner margin extended dorsally, lined with large granules; anterolateral margin gently convex, lined with large granules, not clearly demarcated from posterolateral margin; posterolateral margin gently concave, converg- 


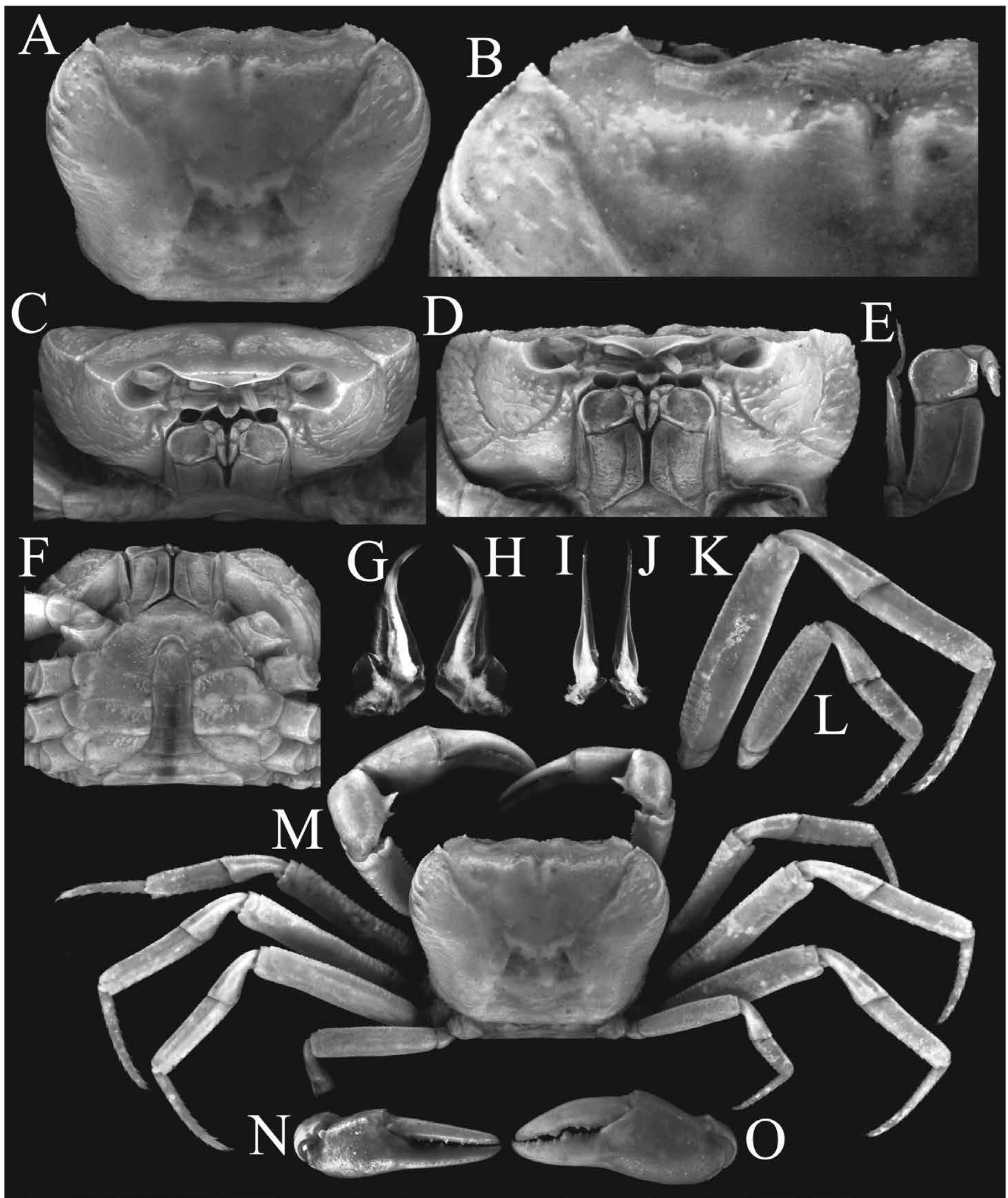

Figure 1. Sundathelphusa prosperidad, new species, holotype male $(30.68 \times 22.3 \mathrm{~mm})(\mathrm{NMCR} 50776)$. A) carapace; B) anterolateral margin; C-D) frontal; E) maxilliped; F) ventral view; G-H) left G1, ventral and dorsal views; I-J) left G2, ventral and dorsal views; K) right third ambulatory leg, dorsal view; L) right fourth ambulatory leg, dorsal view; M) habitus, dorsal view; N-O) right and left cheliped. 


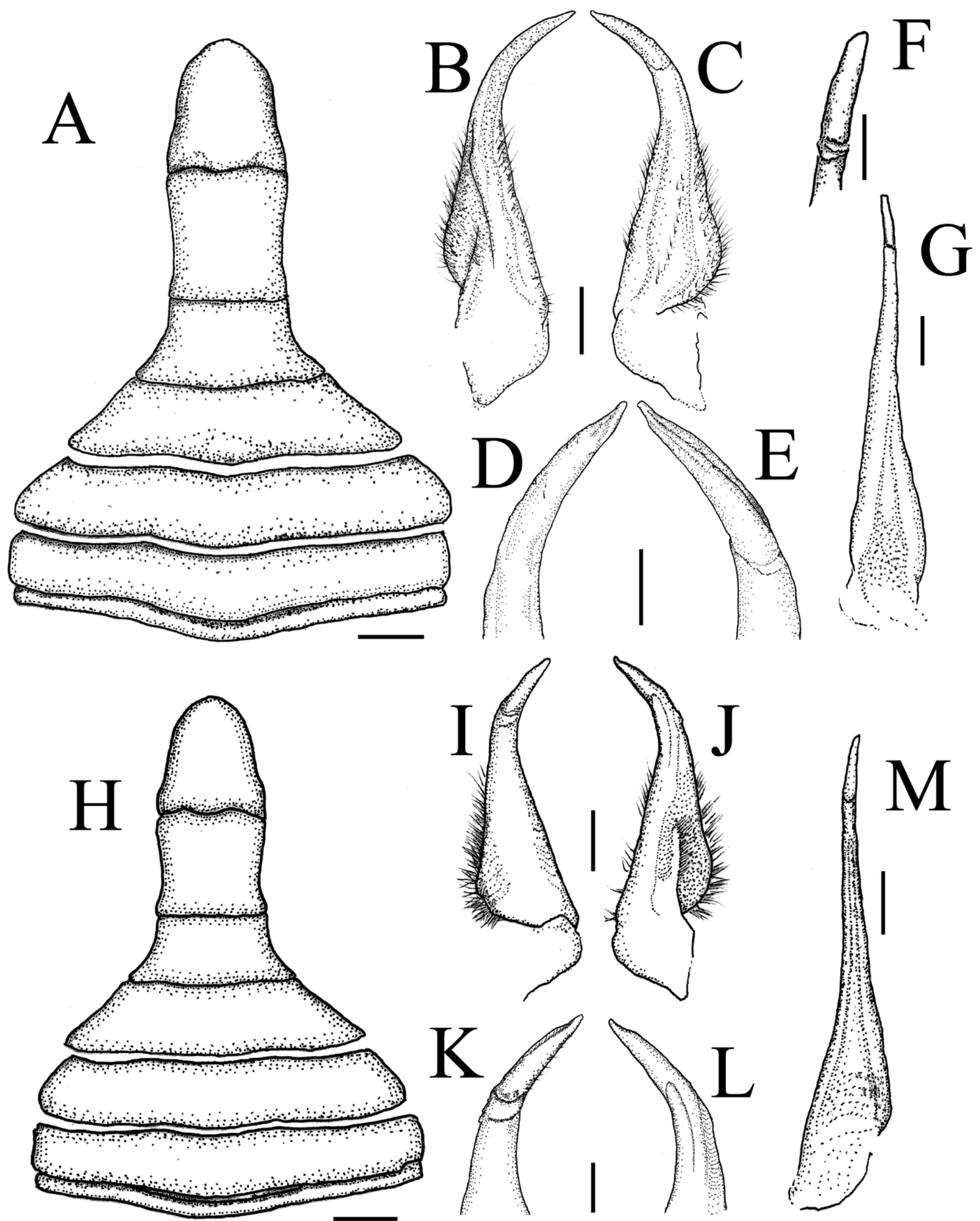

Figure 2. Sundathelphusa prosperidad, new species (A-G holotype male, $30.68 \times 22.3 \mathrm{~mm}$, NMCR 50776; H-M paratype male, $25.33 \times 20.2$ $\mathrm{mm}$, NMCR 50779). A) abdomen; B-C) left G1, ventral and dorsal views; D-E) distal part of left G1, ventral and dorsal views; F) distal part of left G2, ventral view; G) left G2, dorsal view; H) abdomen; I-J) right G1, dorsal and ventral views; K-L) distal part of right G1, dorsal and ventral views; $M$ ) right $\mathrm{G} 2$, ventral view. Scale bars, in $\mathrm{mm}$ : $\mathrm{A}, \mathrm{H}=2$; $\mathrm{B}-\mathrm{C}, \mathrm{I}-\mathrm{J}=1$; $\mathrm{D}-\mathrm{E}, \mathrm{G}, \mathrm{K}-\mathrm{M}=0.5 ; \mathrm{F}=0.25$ 


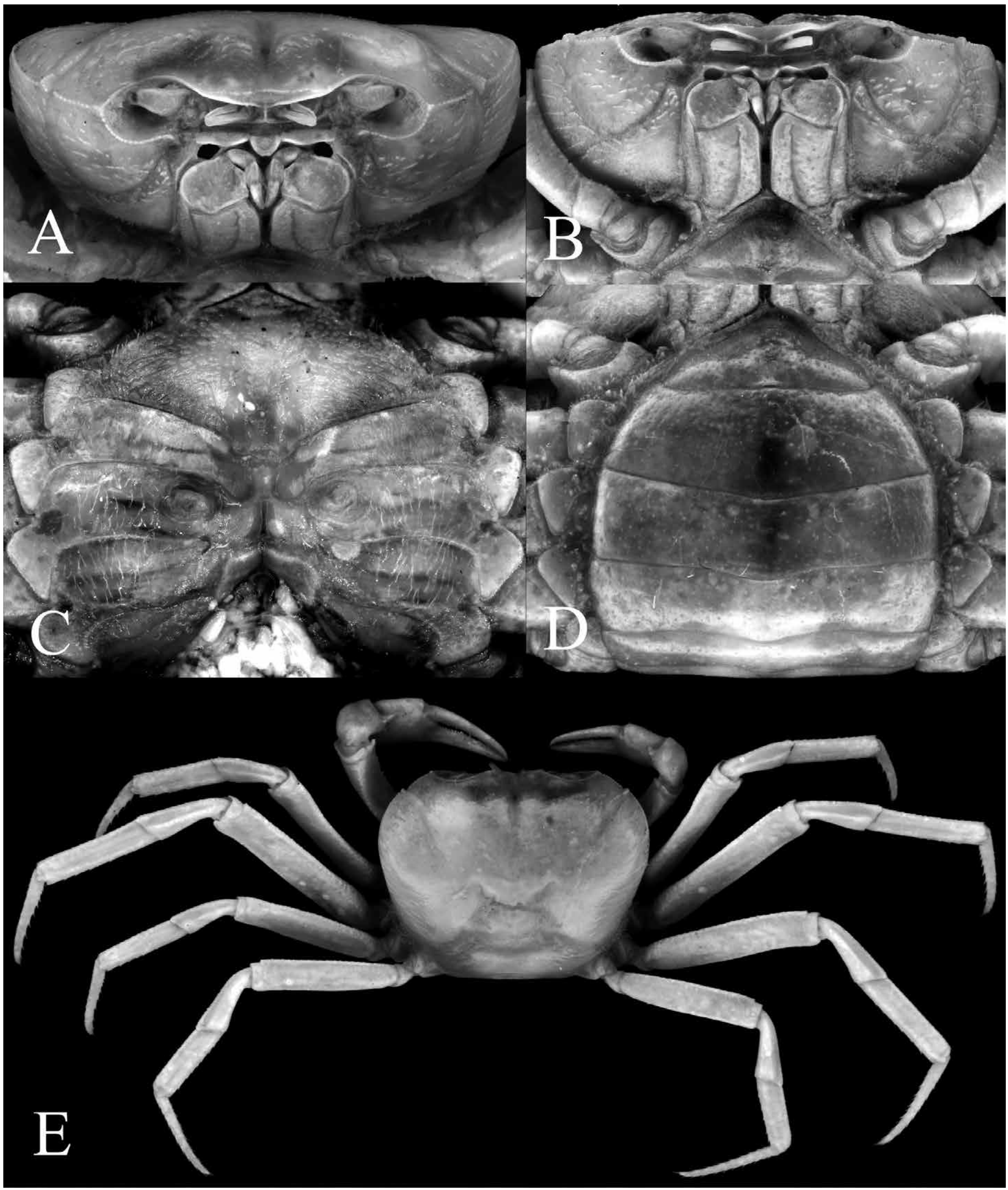

Figure 3. Sundathelphusa prosperidad, new species, paratype female, $(28.04 \times 21.38 \mathrm{~mm})(\mathrm{NMCR} 50777)$. A-B) frontal; C) thoracic sternum showing vulvae; D) abdomen; E) habitus, dorsal view. 


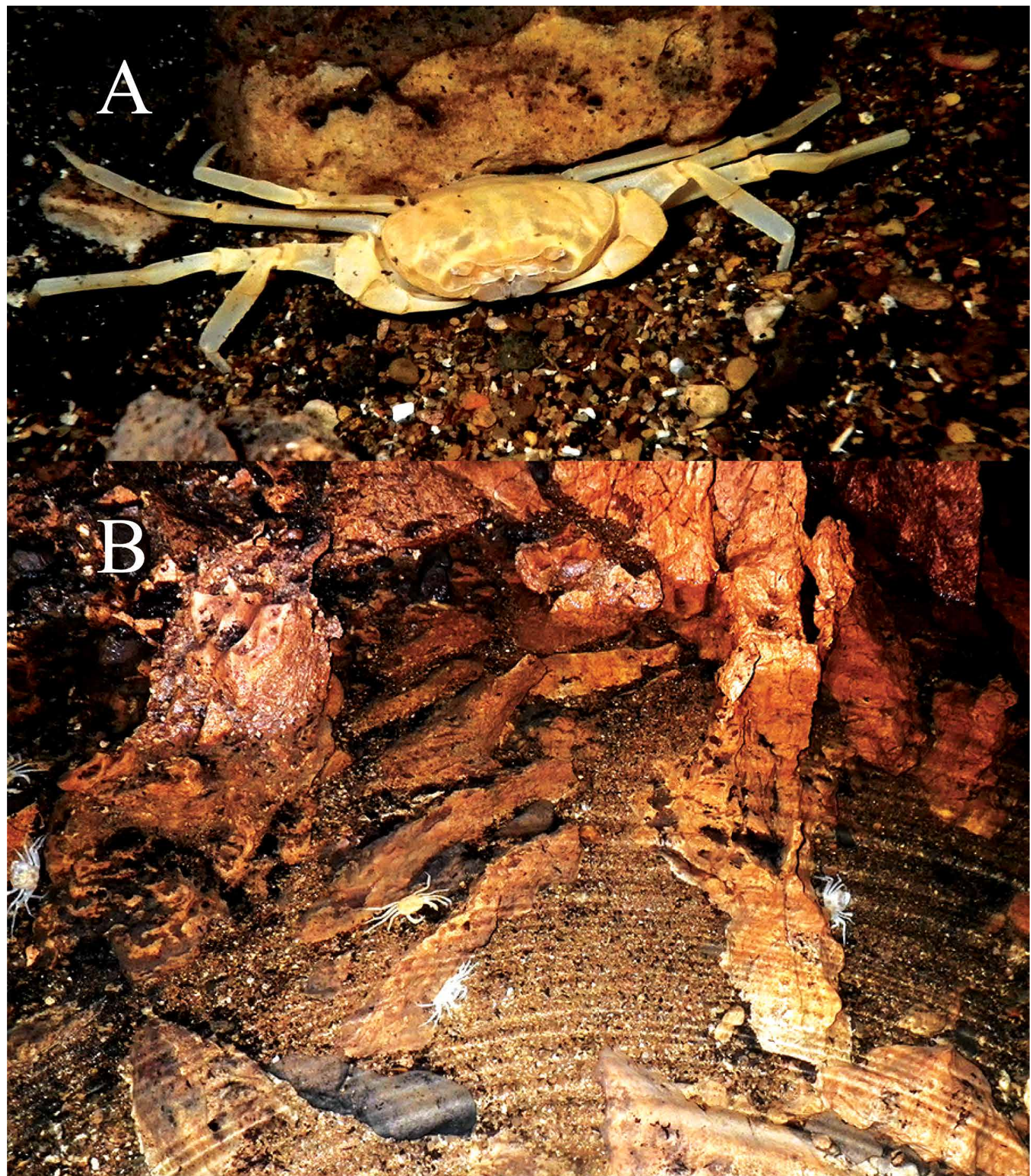

Figure 4. Sundathelphusa prosperidad, new species, in its natural habitat. A) live coloration; B) small colony of the new species in the clear subterranean water inside Ognop Cave.

ing gradually towards posterior margin of carapace (Figs. 1A, 1B, 1C, 1D, 1M). Frontal medial triangle complete; dorsal and lateral margins distinct, granulose, not fused; dorsal margin concave, lateral margins protruded distally over lateral ends of dorsal margin; orbit well developed; supraorbital margin granulated, sinuous; infraorbital margin beaded with distinct granules; outer edge reaching and fused with anterolateral margin; suborbital and subbranchial regions covered with scattered oblique long and short striae as well as small granules; pterygostomial region smooth with oblique ridges on upper outer region (Figs. 1C, 1D). Epistome divided into three lobes; median lobe large, circular, shallow notch present ventrally; lateral lobes wider and less protruded, sinuous, placed more anteriorly than median lobe (Figs. 1C, 1D). 
Eyes reduced, tapering, cornea with traces of pigment, occupy two-thirds of orbit (Figs. 1C, 1D). Basal antennular segment large, subquadrate, flagellum long; antenna with long flagellum, distal end reaching beyond tip of eye when stretched laterally. Ischium of third maxilliped rectangular, bearing distinct oblique submedian sulcus; merus quadrate with shallow median depression; tip of exopod reaching to midpoint of outer margin of merus, with long flagellum (Fig. 1E).

Chelipeds noticeably elongated, subequal, stronger in males; all margins of merus serrated, ventral outer and inner margins more distinct, dorsal margin without distinct subdistal tooth, carpus armed with strong distal sharply-pointed inner angle, flattened dorso-ventrally, laterally fringed with proximal spines; palm minutely granulated on ventral surface, longer than finger; finger robust, cutting edges armed with many sharp teeth of various sizes (Figs. 1M, 1N, 1O).

Ambulatory legs long, slender, third leg longest, merus of third leg 0.89-0.95 times CL $(n=2)$; dorsal margins of meri indistinctly serrated, with subdistal tooth or spine, ventral margins serrated on first leg, second to fourth smooth; carpi short, with longitudinal submedian ridge on the dorsal surface except fourth leg, widened distally, dorsal margins indistinctly serrated; propodi armed with rows of spines on margins, longer on ventral than dorsal margins; dactyli armed with rows of spines on both margins, spines at ventral margins longer than on dorsal margins (Figs. $1 \mathrm{~K}, 1 \mathrm{~L}, 1 \mathrm{M})$.

Male pleonal cavity reaching to level of proximal quarter of coxae of male chelipeds. Male pleon narrow, T-shaped; first somite very short, proximal and distal margins sinuous; second somite transversely subrectangular; third to fifth somites narrows abruptly; lateral margins of third somite convex, lateral margins of fourth somite straight, fifth somite strongly concave; sixth somite rectangular, longer than broad, lateral margins concave; telson subtriangular, longer than broad, lateral margins slightly concave, rounded distally (Figs. 1F, 2A, 2H).

G1 relatively slender; subterminal segment curved outward by distal half, outer margin distinctly concave; terminal segment, bended outward by almost $40-45^{\circ}$, straight, cylindrical, slightly setose, tapering towards distal end (Figs. G1, 1H, 2B, 2C, 2D, 2E, 2I, 2J, 2K, 2L). G2 straight, longer than G1, flagellum short (Figs. 1L, 1J, 2F, 2G, 2M).

Notes on the paratypes. All the paratypes agree well with almost all the major non-sexual characters of the holotype except for varied degree of pigmentation in the eyes (Figs. 1C, 1D, 3A, 3B, 4A). This new species exhibits sexual dimorphism. Oblique granules of striae in the branchial region of the carapace are stronger in males than females. The female possesses large semi-circular vulvae covered by the abdomen at the submedian level of fifth somite, abdomen is rounded with triangular telson (Figs. 3C, 3D). Right and left chelipeds (Fig. 3E) of the females are sub-equal in size but the larger one appeared weaker than that of the males. Granules on the ventral surface of the palm of the cheliped are more prominent in males, with the surface almost smooth in females.

Coloration. Pigmentless, dorsal surface white to pale yellow, ventral surface white (Fig. 4).

Etymology. Named after the Prosperidad town, the species type locality, also a Spanish/Filipino word that means prosperity or success, alluding to the species' successful colonization of the subterranean ecosystem. Used as a noun in apposition.

Habitat and Distribution. Sundathelphusa prosperidad, new species, is known only from Ognop Cave, the type locality of the new species, and Lorenzo Cave, both located within the karst system of Prosperidad, Agusan del Sur. The caves are part of an Oligocene-Miocene limestone formation (MGB, 2010) in Agusan del Sur, Mindanao Island, the Philippines.

This new species occurs in small numbers near the vertical entrance of Ognop Cave (Fig. 4). Two samples of S. prosperidad, new species, were collected from Lorenzo Cave (NMCR 50778, male $20.58 \times 16.67 \mathrm{~mm}$; female $25.77 \times 20.19 \mathrm{~mm}$ ). This distribution clearly suggests that Lorenzo Cave and Ognop Cave are interconnected and the possibility that other colonies could be present in other unexplored areas of the cave system.

Ognop Cave is a long cave system with fragments of sharp, brittle rock boulders along its shallow subterranean river and deep pools. Lorenzo Cave is just a few meters long with a subterranean stream that flows towards its entrance. The water originates from a sump that makes it impassable and cannot be explored further without the use of diving equipment. This cave is located southeast of the Ognop Cave entrance.

Co-inhabitants of the groundwater of Ognop Cave are species of cave goby Caecogobius personatus Larson and Husana, 2017, unidentified cyprinid fish (manuscript in preparation), and atyid shrimps. A colony of bats, a large population of crickets and other invertebrates are also present inside the cave.

The spring that comes out from the rubble of the collapsed portion of the entrance of Ognop Cave is the headwater of one of the major tributaries of the Bega River traversing Bega Falls.

Remarks. Sundathelphusa prosperidad, new species, closely resembles Sundathelphusa hades Takeda and Ng, 2001. However, S. prosperidad possesses the following characters that differentiate it from $S$. hades: 1) quadrate to trape- 
zoidal carapace with proportionately wider breadth at about its one-third level (vs. squarish and narrower breadth in $S$. hades) (Figs. 1A, 1M, 3E vs. Takeda and Ng 2001, figs. 1a, 1b, 1e); 2) presence of a deep notch between the external orbital tooth and epibranchial tooth of the antero-lateral margin (vs. small or shallow in S. hades) (Figs. 1A, 1B, 1C, 1D, $1 \mathrm{M}, 3 \mathrm{~A}, 3 \mathrm{~B}, 3 \mathrm{E}$ vs. Takeda and $\mathrm{Ng} 2001$, figs. 1a, 1b, 1c, 1e, 2a); 3) presence of a granulated crest formed as dorsal extension of the inner margin of the epibranchial tooth (vs. absent in $S$. hades) (Figs. 1A, 1B, 1C, 1D, 1M, 3A, 3B, 3E vs. Takeda and $\mathrm{Ng} \mathrm{2001}$, figs. 1a, 1b, 1c, 1e, 2a); and 4) the distal part of the subterminal segment of the $\mathrm{G} 1$ is strongly curved outwards (vs. relatively straighter in S. hades) (Figs. 1G, 1H, 2B, 2C, 2D, 2E, 2I, 2J, 2K, $2 \mathrm{~L}$ vs. Takeda and $\mathrm{Ng}$ 2001, figs. 3c,3d).

Both S. prosperidad and $S$. hades inhabit caves hence possessing strongly reduced eyes, with a small trace of pigmentation at the tip of the cornea (see Figs. 1C, 1D, 3A, 3B; Takeda and Ng 2001, figs. 1c, 2a, 2b). Such a degree of troglomorphism has also been observed in other freshwater crabs described from caves in the Philippines such as $S$. cavernicola Ng and Sket, 1996, S. sottoae Ng and Sket, 1996, S. lobo Husana, Naruse and Kase 2009, and S. waray Husana, Naruse and Kase 2009.

Sundathelphusa prosperidad, new species, and S. hades are both located in Agusan del Sur in the eastern part of Mindanao Island, and their type localities are close to each other. But unlike the overlapping habitat range of $S$. sottoae and S. cavernicola in Bohol Island, the habitats of these two cave species from Mindanao Island are separated by the extension of the Philippine fault-line and Oligocene-Miocene volcanic deposits (MGB, 2010). The type locality of $S$. prosperidad, new species, is a cave in an Oligocene-Miocene limestone formation, north of the type locality of $S$. hades, a cave in a younger Pliocene-Pliestocene limestone formation (MGB, 2010). Attempts to obtain fresh samples of $S$. hades from the type locality were in vain due to the security situation in the area.

About 98 percent of freshwater crabs in the Philippines are endemic to the archipelago and most of them are data deficient (Cumberlidge et al, 2009). Although there is a possibility that colonies of $S$. prosperidad are present in some unexplored areas of Ognop Cave, the population estimate of this new species may not go beyond 1,000 individuals, it has a small geographic range, and with a very small and restricted area of occupancy. Under IUCN Red List, this new species can be categorized between endangered to critically endangered species under Criterion B1 $\left(<100 \mathrm{~km}^{2}\right.$ extent of occurrence), Criterion B2 ( $<10 \mathrm{~km}^{2}$ area of occupancy), Criterion C ( $<2,500$ mature individuals), and Criterion $\mathrm{D}(<$ $\times 250$ mature individuals per area inside the cave system).

Cave-obligate species in the Philippines are strictly endemic to the cave system they inhabit and cannot be found anywhere else. Similar to the Sundathelphusa prosperidad, new species, other cave crabs such as $S$. cavernicola Takeda, 1983, S. sottoae $\mathrm{Ng}$ and Sket, 1996, S. hades Takeda and Ng, 2001, S. waray Husana, Naruse and Kase, 2009, S. lobo Husana, Naruse and Kase, 2009, and Samarplax principe Husana, Tan and Kase, 2011; cave fishes such as Caecogobius cryptophthalmus Berti and Ercolini, 1991, and C. personatus Larson and Husana, 2019, and other cave-obligate species can fall into the same category. The limited distributional range, the restricted confinement in the cave habitat and small population size of cave-obligate species made them extremely vulnerable to human disturbance. Forest logging, slash and burn farming, and land conversion are common practice that will seriously threaten the cave and its inhabitants and should be strictly prohibited in the surrounding areas above the cave system. The increasing popularity of tourism in the country also poses a serious threat in this stenotopic species. Hence, it is strongly recommended that Ognop Cave and all other caves with cave-obligate species, as well as its surface vegetation, should be strictly protected to preserve the natural habitat of these species and other unique cave organisms.

\section{Acknowledgements}

I express my heartfelt gratitude to my friends in Prosperidad for their unwavering support for my field research in Agusan del Sur. There are no exact words to utter how thankful I am for their hospitality, generosity, and field assistance during my many research trips, as well as for their enthusiasm in protecting and preserving the local natural resources: the Honorable Mayor Albin Magdamit and his staff, especially Noradel Martinez and Marigyn Kamita who facilitated the activities every time I visited the site; the PMC outdoor group, especially Arnel Pasilan who originally discovered the new species, Almar Lambaco, Joelito Dumdum, Winsome Berdida and Joseph Mortiz for their assistance in my many biological expeditions in the region; and the barangay chairman, Benecio Manliguez, for providing security and a local guide during field research trips. My many thanks to Prof. P.K.L. Ng for his guidance in crab taxonomy and hosting me during my research fellowships at NUS. His constructive comments and suggestions were so valuable for the improvement of this manuscript. I also appreciate the assistance of M. Manuel-Santos of the Philippine National Museum and J.C.E. Mendoza of the Lee Kong Chian Museum of Natural History for facilitating the storage of the specimens. This work was funded by the UP System Enhanced Creative Work and Research Grant (ECWRG 2017-2-008). This research is permitted by the Department of Environment and Natural Resources (Wildlife Gratuitous Permit No. R132014-004). 


\section{References}

Berti, R. and Ercolini, A., 1991, Caecogobius cryptophthalmus n. gen. n. sp. (Gobiidae Gobiinae), the first stygobic fish from Philippines: Tropical Zoology, v. 4, no. 1, p. 129-138. DOI: 10.1080/03946975.1991.10539482

Bott, R., 1969, Flußkrabben aus Asien und ihre Klassifikation (Crustacea, Decapoda): Senckenbergiana Biologica, v. 50, p. $359-366$.

Cumberlidge, N., Ng, P.K.L., Yeo, D.C.J., Magalhães, C., Campos, M.R., Alvarez, F., Naruse, T., Daniels, S.R., Esser, L.J., Attipoe, F.Y.K., Clotilde-Ba, F.-L., Darwall, W., Mclvor, A., Baillie, J.E.M., Collen, B., and Ram, M., 2009, Freshwater crabs and the biodiversity crisis: importance, threats, status, and conservation challenges: Biological Conservation, v. 142, p. 1665-1673. https://doi.org/10.1016/j.biocon.2009.02.038

Davie, P.J.F., Guinot, D. and Ng, P.K.L., 2015, Phylogeny of Brachyura: in Castro, P., Davie, P.J.F., Guinot, D., Schram, F., and Von Vaupel Klein, C., eds., Treatise on Zoology - Anatomy, Taxonomy, Biology: The Crustacea, complementary to the volumes translated from the French of the Traité de Zoologie, v. 9(C) (I), Decapoda: Brachyura (Part 2), p. 922-979.

Husana, D.E.M., Kase, T., and Mendoza, J.C.E., 2015, Two new species of the freshwater crab genus Sundathelphusa Bott, 1969 (Crustacea: Brachyura: Gecarcinucidae) from Negros Island, Philippines: Raffles Bulletin of Zoology, v. 63, p. 226-236. http://zoobank.org/urn:Isid:zoobank.org:pub:549829D6-65A9-4D97-B15E-361755F7577B

Husana, D.E.M., Naruse, T., and Kase, T., 2009, Two new cavernicolous species of the genus Sundathelphusa from Western Samar, Philippines (Decapoda: Brachyura: Parathelphusidae): Journal of Crustacean Biology, v. 29, no. 3, p. 419-427. https://doi.org/10.1651/08-3081.1

Husana, D.E.M., Naruse, T., and Kase, T., 2010, A new species of the genus Karstarma (Crustacea: Decapoda: Brachyura: Sesarmidae) from Anchialine Caves in the Philippines: Raffles Bulletin of Zoology, v.58, no. 1, p. 65-69.

Husana, D.E.M., and Ng, P.K.L., 2019, On the identity of Sundathelphusa philippina (von Martens, 1868) (Decapoda: Brachyura: Gecarcinucidae) from the Philippines, with descriptions of two new species: Zootaxa, v. 4585, no. 2, p. 315-331. https://doi.org/10.11646/zootaxa.4585.2.5

Husana, D.E.M., Tan, S.H., and Kase, T., 2011, A new genus and species of anchialine Hymeosomatidae (Crustacea: Decapoda: Brachyura) from Samar, Philippines: Zootaxa, v. 3109, p. 49-59. https://doi.org/10.11646/zootaxa.3109.1.3

Husana, D.E.M., Yamamuro, M., and Ng, P.K.L., 2014, Two new species of freshwater crabs of the genus Sundathelphusa Bott, 1969 (Decapoda: Brachyura: Gecarcinucidae) from caves in Luzon, Philippines: Zootaxa, v. 3815, no. 4., p. 565-574. https://doi.org/10.11646/zootaxa.3815.4.6

Klaus, S., Mendoza, J.C.E., Liew, J.H., Plath, M., Meier, R., and Yeo, D.C.J., 2013, Rapid evolution of troglomorphic characters suggests selection rather than neutral mutation as a driver of eye reduction in cave crabs: Biology Letters, v. 9, 20121098. https://doi.org/10.1098/ rsbl.2012.1098

Larson, H.K., and Husana, D.E.M., 2019, A new species of the blind goby Caecogobius (Govioidei, Gobiidae, Gobinellinae) from a cave system in Mindanao, Philippines: Ichthyological Research, v. 66, no. 1, p. 97-103. Published online: 6 October 2018. https://doi.org/10.1007/s10228018-0659-y

Martens, E. von, 1868, Ueber einige neue crustacean: Monatsberichte der Königlichen Preussische Akademie der Akademie der Wissenschaften zu Berlin: Sitzung der Physikalisch-mathematische Klasse, 1868:.in Mines and Geosciences Bureau, 2010, Geology of the Philippines, $2^{\text {nd }}$ edition: p. 608-615, Department of Environment and Natural Resources, 532 pages.

Ng, N.K., and Ng, P.K.L., 2009, Orcovita holthuisi, a new species of anchialine crab (Brachyura, Varunidae) from Coron Island, Palawan, Philippines: Crustaceana, v. 82, no. 9, p. 1097-1108. https://doi.org/10.1163/156854009X407678

Ng, P.K.L., 2002, New species of cavernicolous crabs of the genus Sesarmoides from the western Pacific, with a key to the genus (Crustacea: Decapoda: Brachyura: Sesarmidae): Raffles Bulletin of Zoology, v. 50, no. 2, p. 419-435.

Ng, P.K.L., 2010, On the identity of Para-Bary-Thelphusa grapsoides longipes Balss, 1937, with description of a new species from the Philippines (Brachyura, Gecarcinucidae): in Fransen, C.H.J.M., De Grave S., and Ng, P.K.L., eds., Studies on Malacostraca: Lipke Bijdeley Holthuis Memorial Volume: Crustaceana Monographs, v. 14, p. 561-571.

Ng, P.K.L., and Guinot, D., 2001, On the land crabs of the genus Discoplax A. Milne Edwards, 1867 (Crustacea: Decapoda: Brachyura: Gecarcinidae), with description of a new cavernicolous species from the Philippines: Raffles Bulletin of Zoology, v. 49, no. 2, p. 331-338.

Ng, P.K.L., and Sket, B., 1996, The freshwater crab fauna (Crustacea: Decapoda: Brachyura) of the Philippines. IV. On the collection of Parathelphusidae from Bohol: Proceeding of the Biological Society of Washington, v. 109, p. 695-706.

Ng, P.K.L., Guinot, D., and Iliffe, T.M., 1996, Revision of the anchialine varunine crabs of the genus Orcovita Ng and Tomascik, 1994 (Crustacea: Decapoda: Brachyura: Grapsidae), with descriptions of four new species: Raffles Bulletin of Zoology, v. 44, no. 1, p. $109-134$.

Rathbun, M.J., 1904, Les crabes d'eau douce (Potamonidae): Nouvelles Archives du Muséum d'Histoire Naturelle, 4e ser., v. 6, p. 225-311, pls. 9-18.

Stasolla, G., Abbarchi, A., and Innocenti, G., 2015, Sundathelphusa spelaeophila, a new species of cavernicolous crab from Samar, Philippines (Decapoda: Brachyura: Gecarcinucidae): Raffles Bulletin of Zoology, v. 63, p. 448-453.

Stasolla, G. and Innocenti, G., 2014, A new species of cavernicolous crab from Coron Island, Palawan, the Philippines (Decapoda: Brachyura: Varunidae): Raffles Bulletin of Zoology, v. 62, p. 591-599.

Takeda, M., 1983, A new cavernicolous crab from Bohol, the Philippines: Bulletin of the National Science Museum, Tokyo, Series A, v. 9, p.169-173.

Takeda, M., and Ng, P.K.L., 2001, The freshwater crab fauna (Crustacea, Brachyura) of the Philippines: VI. A new cavernicolous crab from Mindanao: Zoological Science, v. 18, p. 1123-1127. https://doi.org/10.2108/zsj.18.1123 